\title{
酸 New Disease Reports \\ First report of blackleg and soft rot of potato caused by Pectobacterium carotovorum subsp. brasiliensis in New Zealand
}

\author{
P. Panda ${ }^{1}$, M.A.W.J. Fiers ${ }^{2}$, K. Armstrong ${ }^{1}$ and A.R. Pitman ${ }^{1,2 *}$ \\ ${ }^{1}$ Bio-Protection Research Centre, Lincoln University, PO Box 84, Canterbury, New Zealand; ${ }^{2}$ New Zealand Institute for \\ Plant \& Food Research Ltd, Private Bag 4704, Christchurch, New Zealand
}

*E-mail: Andrew.Pitman@lincoln.ac.nz

Received: 14 Jun 2012. Published: 19 Sep 2012. Keywords: Erwinia, enterobacteria, multi-locus sequence analysis, 16 S rRNA gene

Blackleg and stem rot of potato occur sporadically in New Zealand, causing economic damage under optimal temperature and humidity conditions for disease development. Both Pectobacterium atrosepticum $(P b a)$ and $P$. carotovorum subsp. carotovorum $(P c c)$ have previously been isolated from potato tubers with soft rot symptoms in New Zealand (Crowhurst \& Wright, 1998) whereas only Pba has been shown to cause blackleg. A collection of 89 enterobacteria were recently isolated from potato tubers from commercial crops in the Auckland, Waikato, Manawatu-Wanganui and Canterbury regions of New Zealand. The majority were initially assigned as $P c c$ by their growth at $37^{\circ} \mathrm{C}$, carbon utilisation profiles and restriction fragment length polymorphisms (Pitman et al., 2008). These isolates were mostly unable to cause blackleg symptoms, although several were shown to be highly aggressive upon stem infection. Further characterisation of these aggressive isolates using PCR assays to distinguish $P c c$ from $P$. carotovorum subsp. brasiliensis $(\mathrm{Pbr})$ was carried out using primers EXPCCF and EXPCCR (Kang et al., 2003) and Br1f and L1r (Duarte et al., 2004), respectively. From 18 isolates, occurring throughout the four major growing localities (Fig. 1), a 322-bp fragment specific to $\mathrm{Pbr}$ was amplified using Br1f and L1r (Fig. 2), whereas no PCR product (550-bp) was obtained typical of Pcc. The 16S rRNA gene was amplified (Wang \& Wang, 1996) from one of the putative $\mathrm{Pbr}$ isolates, NZEC1 (deposited in the International Collection of Microbes from Plants as ICMP 19477). BLAST analysis of the 16S rRNA DNA sequence (GenBank Accession No. JQ771053) showed 100\% identity to the $16 \mathrm{~S}$ rRNA of $\mathrm{Pbr}$.

Multi-locus sequence analysis was performed using concatenated DNA sequences of acnA, gapA, icdA, $m d h, m t l D, p g i$ and $p r o A$ from NZEC1 (JQ820114-JQ820120) and 46 related taxa (Ma et al., 2007). The resulting majority rule consensus tree constructed using MrBayes v. 3.0b4 (Fig. 3) clustered NZEC1 with $P b r$, readily distinguishing it from the closely related subspecies $P c c$. Pathogenicity assays were conducted using potato plants (cv. 'Ilam Hardy') by injecting $10 \mu \mathrm{l}$ of a bacterial suspension (10 $\mathrm{cfu} / \mathrm{ml}$ ) into either stems or tubers. Each time, severe blackleg (Fig. 4) or tuber soft rot (Fig. 5) were observed on plants inoculated with $\mathrm{Pbr}$ whereas $P c c$ strains were unable to cause blackleg. The results were consistent with observations throughout the world that suggest $P c c$ is largely unable to cause this stem disease.

To our knowledge, this is the first report of $P b r$ infecting potato in New Zealand.The prevalence of $\mathrm{Pbr}$ isolates in Canterbury is of particular note due to the high proportion of seed tuber production that takes place in this region. As $P c c$ is usually unable to cause blackleg and $P b a$ is only rarely isolated from tubers in New Zealand (Pitman et al., 2008), $\mathrm{Pbr}$ is likely to be an important component of the blackleg syndrome in New Zealand. Consequently, this pathogen is expected to contribute to economic losses resulting from both blackleg and tuber soft rot. $\mathrm{Pbr}$ also causes severe economic impacts both in Brazil and South Africa.

\section{References}

Crowhurst RN, Wright PJ, 1998. Subspecies of Erwinia carotovora causing blackleg of potato in Pukekohe and Pukekawa and their survival in soils. New Zealand Potato Bulletin 109, 20-22.

Duarte V, De Boer SH, Ward LJ, de Oliveira AMR, 2004.

Characterization of atypical Erwinia carotovora strains causing blackleg of potato in Brazil. Journal of Applied Microbiology 96, 96:535. [http://dx.doi.org/10.1111/j.1365-2672.2004.02173.x]

Kang HW, Kwon SW, Go SJ, 2003. PCR-based specific and sensitive detection of Pectobacterium carotovorum ssp. carotovorum by primers generated from a URP-PCR fingerprinting-derived polymorphic band. Plant Pathology 52, 127.

[http://dx.doi.org/10.1046/j.1365-3059.2003.00822.x]

Ma B, Hibbing ME, Kim HS, Reedy RM, Yedidia I, Breuer Jane, Breuer Jeffrey, Glasner JD, Perna NT, Kelman A, Charkowski AO, 2007. Host range and molecular phylogenies of the soft rot Enterobacterial genera Pectobacterium and Dickeya. Phytopathology 97, 1150-1163.

[http://dx.doi.org/10.1094/PHYTO-97-9-1150]

Pitman AR, Wright PJ, Galbraith MD, Harrow SA, 2008. Biochemical and genetic diversity of pectolytic enterobacteria causing soft rot disease of potatoes in New Zealand. Australasian Plant Pathology 37, 559-568. [http://dx.doi.org/10.1071/AP08056]

Wang GCY, Wang Y, 1996. The frequency of chimeric molecules as a consequence of PCR co-amplification of 16S rRNA genes from different bacterial species. Microbiology 142, 1107-1114. [http://dx.doi.org/10.1099/13500872-142-5-1107]

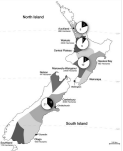

Figure 1

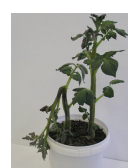

Figure 4

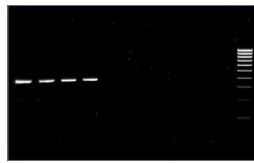

Figure 2

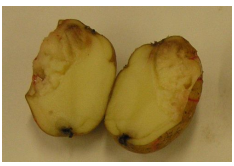

Figure 3

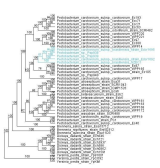

To cite this report: Panda P, Fiers MAWJ, Armstrong K, Pitman AR, 2012. First report of blackleg and soft rot of potato caused by Pectobacterium carotovorum subsp. brasiliensis in New Zealand. New Disease Reports 26, 15.

[http://dx.doi.org/10.5197/j.2044-0588.2012.026.015] 